U.S. Department of Energy

Grand Junction Projects Office Remedial Action Project

Final Report of the Decontamination and Decommissioning of Building 34 at the Grand Junction Projects Office Facility

August 1996
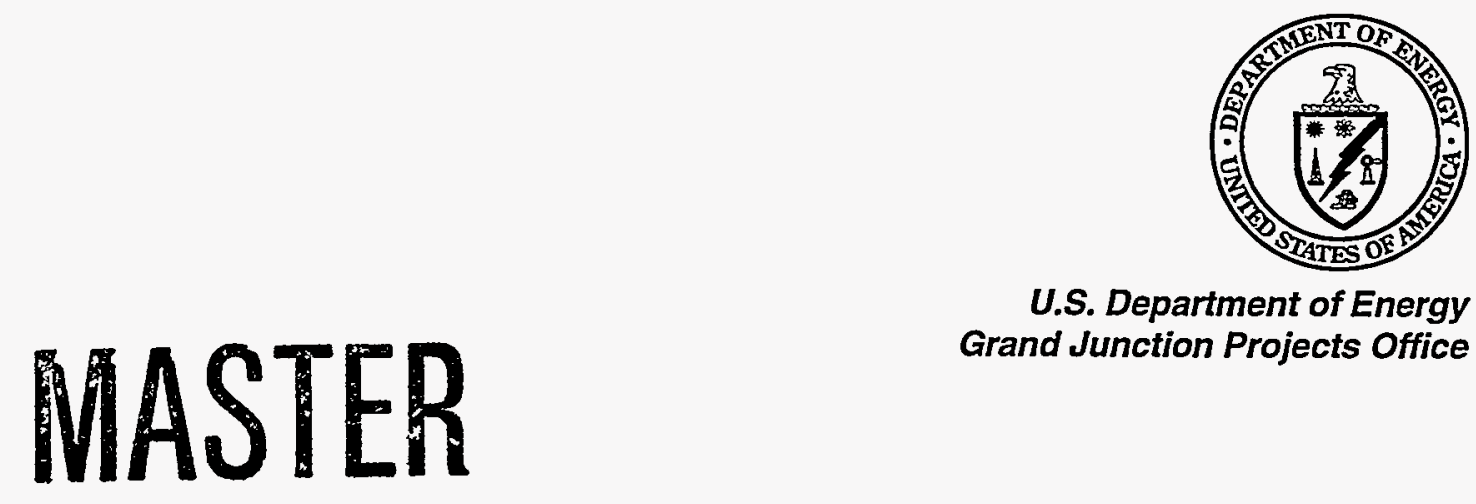

U.S. Department of Energy Grand Junction Projects Office 
This report was prepared as an account of work sponsored by an agency of the United States Government. Neither the United States Government nor any agency thereof, nor any of their employees, makes any warranty, express or implied, or assumes any legal liability or responsibility for the accuracy, completeness, or usefulness of any information, apparatus, product, or process disclosed in this report, or represents that its use would not infringe privately owned rights. Reference herein to any specific commercial product, process, or service by trade name, trademark, manufacturer, or othenwise, does not necessarily constitute or imply its endorsement, recommendation, or favoring by the United States Government or any agency thereof. The views and opinions of authors expressed herein do not necessarily state or reflect those of the United States Government or any agency thereof. 


\section{Final Report \\ of the Decontamination and Decommissioning of Building 34 at the Grand Junction Projects Office Facility}

August 1996

Prepared for

U.S. Department of Energy

Albuquerque Operations Office

Grand Junction Projects Office

Prepared by

Rust Geotech

Grand Junction, Colorado

Technical Coordination and Reports Project Number TCR-031-0006-00-000

Technical Coordination and Reports Document Number T0001600

Rust Geotech has been granted authorization to conduct remedial action under the Decontamination and Decommissioning Program. Remedial action was conducted in accordance with all applicable or relevant and appropriate requirements.

Work Performed Under DOE Contract No. DE-AC04-86ID12584

Approved for public release; distribution is unlimited. 
This page intentionally blank 
Signature Page

Prepared by:

Bushel edveddun

M. R. Widdop, Project Technical Specialist Technical Coordination and Reports Rust Geotech $\frac{\text { August 28, } 1996}{\text { Date }}$
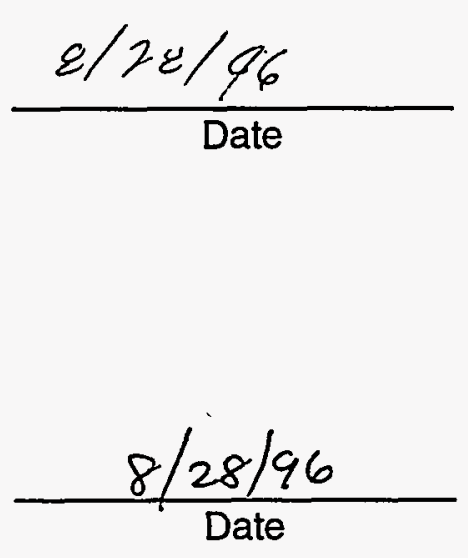

DOE/Grand Junction Projects Office

GJPORAP Final Report of D\&D of Building 34

August 1996

Page iii 
This page intentionally blank 


\section{Abstract}

The U.S. Department of Energy (DOE) Grand Junction Projects Office (GJPO) occupies a 61.7 acre facility along the Gunnison River near Grand Junction, Colorado. This site was contaminated with uranium ore and mill tailings during uranium refining activities of the Manhattan Engineer District and during pilot milling experiments conducted for the U.S. Atomic Energy Commission's domestic uranium procurement program. The DOE Defense Decontamination and Decommissioning Program established the Grand Junction Projects Office Remedial Action Project to clean up and restore the facility lands, improvements, and the underlying aquifer. The site contractor for the facility, Rust Geotech, was also the remedial action contractor.

Building 34 was radiologically contaminated and the building was demolished in 1996 . The soil area within the footprint of the building was analyzed and found to be not contaminated. The area can be released for unlimited exposure and unrestricted use. This document was prepared in response to a DOE request for an individual closeout report for each contaminated GJPO building. 
This page intentionally blank 


\section{Contents}

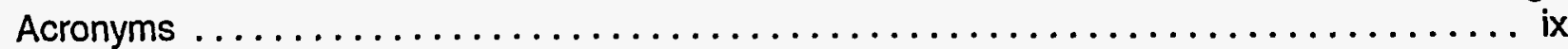

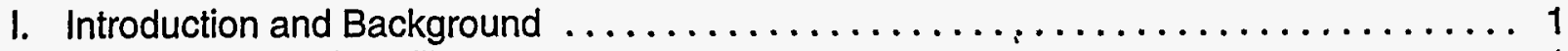

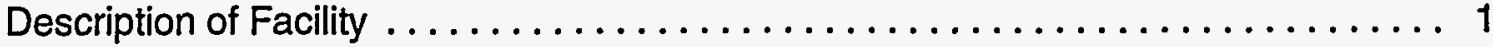

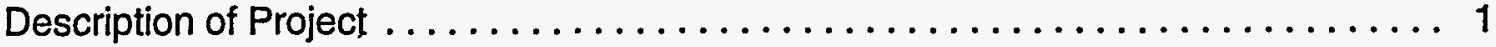

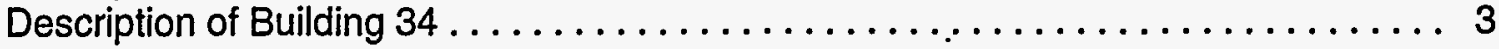

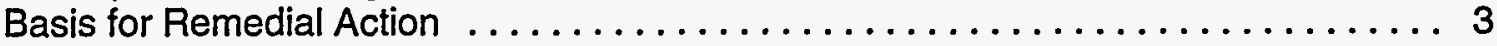

II. Decommissioning Criteria, Objectives, and Work Scope ............... 3

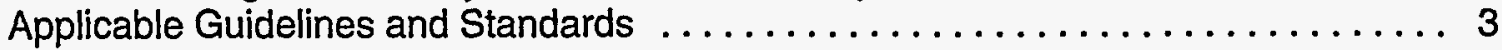

III. Work Performed ................................. 3

Remedial Investigation/Feasibility Study and Record of Decision . . . . . . . . . 3

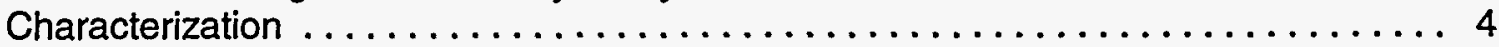

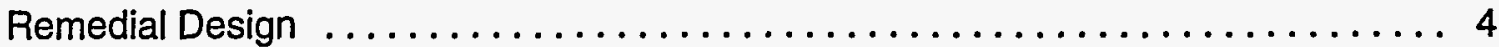

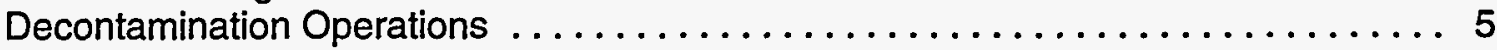

IV. Final Release Survey $\ldots \ldots \ldots \ldots \ldots \ldots \ldots \ldots \ldots \ldots \ldots \ldots \ldots \ldots \ldots \ldots$

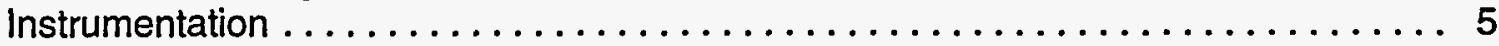

Background Determinations . . . . . . . . . . . . . . . . . . .

Reference Grids . . . . . . . . . . . . . . . . . . . . . . . . 7

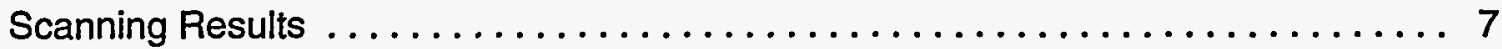

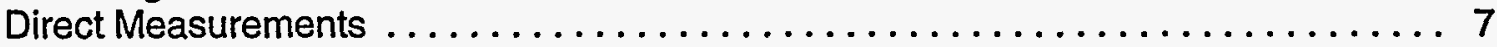

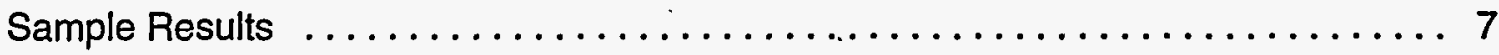

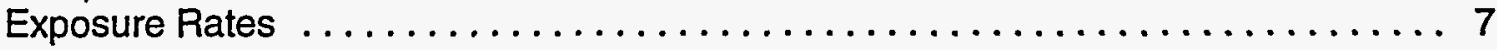

V. Cost and Schedule $\ldots \ldots \ldots \ldots \ldots \ldots \ldots \ldots \ldots \ldots \ldots \ldots \ldots \ldots \ldots$

VI. Occupational Exposure $\ldots \ldots \ldots \ldots \ldots \ldots \ldots \ldots \ldots \ldots \ldots \ldots \ldots \ldots$

VII. Waste Volumes $\ldots \ldots \ldots \ldots \ldots \ldots \ldots \ldots \ldots \ldots \ldots \ldots \ldots \ldots \ldots$

VIII. Final Condition $\therefore \ldots \ldots \ldots \ldots \ldots \ldots \ldots \ldots \ldots \ldots \ldots \ldots \ldots \ldots \ldots$

IX. Lessons Learned $\ldots \ldots \ldots \ldots \ldots \ldots \ldots \ldots \ldots \ldots \ldots \ldots \ldots \ldots \ldots \ldots \ldots$

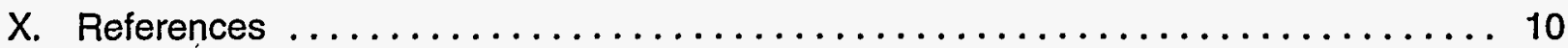

\section{Figures}

Figure 1. Site Map of the DOE-GJPO Facility, Grand Junction, Colorado ..........2

2. Extent of Contamination and Verification Areas $\ldots \ldots \ldots \ldots \ldots \ldots \ldots$ 


\section{Tables}

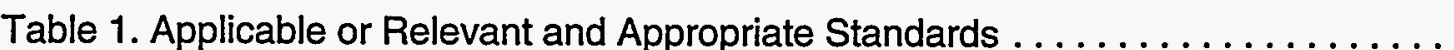

2. Background Values for the DOE-GJPO Facility $\ldots \ldots \ldots \ldots \ldots \ldots \ldots \ldots \ldots \ldots$

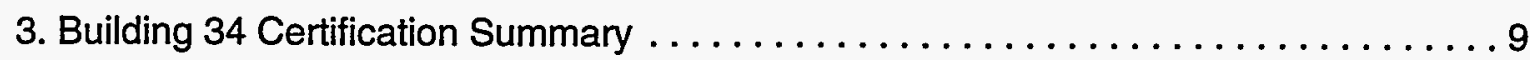

B-1. Post-Remediation Sample/Measurement Results for Exterior Soil Areas ....... . B-3

B-2. Mean Concentrations of $100-\mathrm{m}^{2}$ Soil Areas ..................... B-4

\section{Appendices}

Appendix A. Applicable Program and Quality Assurance Requirements

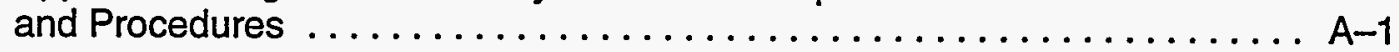

B. Final Radiological Conditions $\ldots \ldots \ldots \ldots \ldots \ldots \ldots \ldots \ldots \ldots$, B-1 


\section{Acronyms}

CERCLA Comprehensive Environmental Response, Compensation, and Liability Act

CFR U.S. Code of Federal Regulations

D\&D Decontamination and Decommissioning

DOE U.S. Department of Energy

FS Feasibility Study

FUSRAP Formerly Utilized Sites Remedial Action Program

GJPO Grand Junction Projects Office

GJPORAP Grand Junction Projects Office Remedial Action Project

IVC Independent Verification Contractor

LTSM Long-Term Surveillance and Maintenance

QA quality assurance

RAC Remedial Action Contractor

RCRA Resource Conservation and Recovery Act

RDC Radon Decay-product Concentration

ROD Record of Decision

SARA Superfund Amendments and Reauthorization Act

SFMP Surplus Facilities Management Program

U.S.C. United States Code

$\mathrm{V}$-area verification area 
This page intentionally blank 


\section{DISCLAIMER}

Portions of this document may be illegible in electronic image products. Images are produced from the best available original document. 


\section{DISCLAIMER}

This report was prepared as an account of work sponsored by an agency of the United States Government. Neither the United States. Government nor any agency thereof, nor any of their employees, makes any warranty, express or implied, or assumes any legal liability or responsibility for the accuracy, completeness, or usefulness of any information, apparatus, product, or process disclosed, or represents that its use would not infringe privately owned rights. Reference herein to any specific commercial product, process, or service by trade name, trademark, manufacturer, or otherwise does not necessarily constitute or imply its endorsement, recommendation, or favoring by the United States Government or any agency thereof. The views and opinions of authors expressed herein do not necessarily state or reflect those of the United States Government or any agency thereof. 


\section{Introduction and Background}

This report summarizes the results of the remedial action conducted on Building 34 at the U.S. Department of Energy (DOE) Grand Junction Projects Office (GJPO) facility. The surfaces of the foundation, floor, and metal structure and skin of this building were radiologically contaminated, and the building was demolished in 1996. The soil within the building footprint complies with applicable regulations and can be released for unrestricted use and unlimited exposure. After all Grand Junction Projects Office Remedial Action Project (GJPORAP) remedial action is completed, the facility is expected to be transferred to the Long-Term Surveillance and Maintenance (LTSM) Program to allow restoration of the aquifer. The remediation of the exterior land areas and the other buildings and associated utilities on the DOE-GJPO facility will be summarized in separate reports.

\section{Description of Facility}

The DOE-GJPO facility is located approximately 0.6 mile ( 1 kilometer) south and west of populated areas of the city of Grand Junction in Sections 26 and 27, Township 1 South, Range 1 West, Ute Principal Meridian, Mesa County, Colorado (Figure 1). The facility occupies approximately 61.7 acres ${ }^{*}$ ( 25 hectares) of floodplain within an accretionary bend along the east bank of the Gunnison River.

The elevation of the DOE-GJPO facility is approximately 4,560 feet (1,390 meters). The facility is situated on silty sandy gravel underlain by mudstone bedrock. Two bodies of water with associated wetlands are located on the DOE-GJPO facility: the North Pond and the South Pond. A freshwater alluvial aquifer underlying the facility is in direct hydraulic contact with the ponds and the Gunnison River. A semi-arid climate prevails.

Access to the occupied portion of the facility is restricted by security personnel and a fence.

\footnotetext{
* Previous to the reacquisition of Black Bridge Park, the facility occupied approximately 56.4 acres.
}

There are approximately 40 structures on the facility. Beyond the fence are vehicle parking lots to the east and an earthen dike along the Gunnison River to the west and north. The area adjacent to the facility to the north was formerly Black Bridge Park, now owned by DOE. The facility is bordered on the east by the Southern Pacific Railroad (formerly the Denver and Rio Grande Western Railroad) right-of-way.

DOE-GJPO facility lands were acquired by the U.S. War Department in 1943 for the Manhattan Engineer District. A refinery was operated on the site from 1943 to 1946 to treat and concentrate uranium oxide. The U:S. Atomic Energy Commission operated a uraniumconcentrate sampling plant and assay laboratory on site until 1974. Pilot-scale uranium ore mills were operated from 1953 to 1958, processing 30,000 tons (27,200 metric tons) of ore (DOE 1987a). Mill operations were the primary source of contaminated materials at the DOE-GJPO facility, resulting in the on-site burial of approximately 247,000 cubic yards $\left(\mathrm{yd}^{3}\right)$, or 189,000 cubic meters $\left(\mathrm{m}^{3}\right)$, of uranium ore tailings. Other potential sources of contamination included laboratory and vehicle-maintenance wastes and by-products and activities related to sampling and stockpiling of uranium concentrates. Approximately 22 acres ( 8.9 hectares) of open land and 19 buildings were contaminated.

\section{Description of Project}

In 1984, the DOE-GJPO facility was accepted into the DOE Surplus Facilities Management Program (SFMP) for the purpose of eliminating health hazards resulting from uranium mill tailings and associated contaminated materials at the facility; and to bring contaminated portions of the facility, including the underlying aquifer, into compliance with applicable environmental regulations. In 1988, the facility was transferred to the DOE Decontamination and Decommissioning (D\&D) Program. The D\&D Program is responsible for the surveillance and maintenance of surplus DOE facilities, including the performance of any 


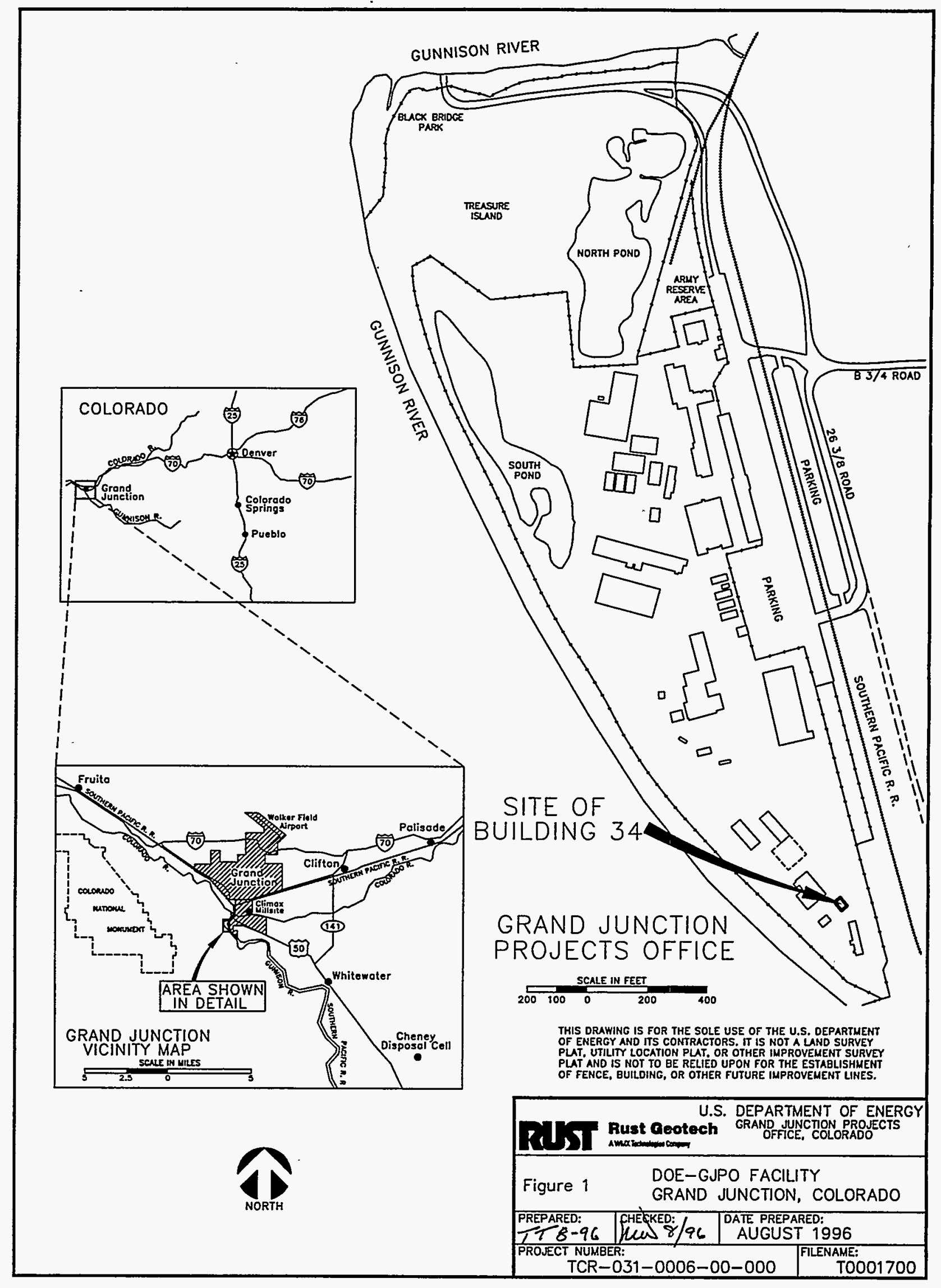

Figure 1. Site Map of the DOE-GJPO Facility, Grand Junction, Colorado 
necessary decontamination and decommissioning activities. DOE-GJPO has specific responsibility for the GJPORAP under the D\&D Program. Rust Geotech is the Remedial Action Contractor. (RAC) for GJPORAP.

The GJPORAP organization and implementation strategy was defined in the Grand Junction Projects Office Remedial Action Project Remedial Action Plan (DOE 1990c).

\section{Description of Building 34}

Building 34 was a steel-frame structure with metal siding and roof and a concrete slab floor, built on a concrete stem wall foundation. The building was constructed in 1954 as a boiler house for the large pilot mill. Subsequently, it was used for storage. The building had a footprint of 800 square feet $\left(\mathrm{ft}^{2}\right)$ or 74 square meters $\left(\mathrm{m}^{2}\right)$.

\section{Basis for Remedial Action}

In 1980, the U.S. Congress enacted the Comprehensive Environmental Response, Compensation, and Liability Act (CERCLA) (42 United States Code [U.S.C.] 9601). In 1986, Congress amended CERCLA with the Superfund Amendments and Reauthorization Act (SARA). Section 120 of SARA and Executive Order 12580 , Superfund Implementation, directed DOE to coordinate with the U.S. Environmental Protection Agency to respond to actual or potentially imminent releases of hazardous substances into the environment at federally owned DOE facilities. D\&D Program policy specifies that remedial action will be conducted in accordance with DOE Order 5480.1B, Environment, Safety, and Health Program for Department of Energy Operations, and all other applicable environmental regulations.

The DOE-GJPO facility was evaluated using the Hazard Ranking System. Although the resulting score of 14.6 (DOE 1989b) did not qualify the facility for placement on the National Priorities List, remedial action under GJPORAP conformed to the applicable provisions of CERCLA, as amended by SARA, and the Uranium Mill Tailings Radiation Control Act (42 U.S.C. 7901), the National Environmental
Policy Act (42 U.S.C. 4321), and other applicable Federal and State regulations. Remedial action was conducted with an emphasis on maintaining all health and safety risks as low as reasonably achievable.

\section{Decommissioning Criteria, Objectives, and Work Scope}

\section{Applicable Guidelines and Standards}

Table 1 presents the guidelines that specify the authorized limits for GJPORAP.

Remedial action activities were conducted in accordance with the Rust Quality Assurance [QA] Manual (Manual 101) and approved plans and procedures (Appendix A), which incorporated the applicable provisions of 10 CFR 830.120, "Quality Assurance Requirements."

\section{Work Performed}

\section{Remedial Investigation/Feasibility Study and Record of Decision}

The Remedial Investigation/Feasibility Study [FS]-Environmental Assessment for GJPORAP was released in 1989 (DOE 1989a). Building 34 was one of the four buildings included in the original scope of GJPORAP and-addressed in the FS. The selected remedial action alternative, detailed in the FS, specified that the building would be decontaminated using vacuuming, pressure washing or abrasion, or localized removal and replacement of building components. The building would be returned to unrestricted use for storage. This alternative was adopted in the Record of Decision (ROD) (DOE 1990a).

Post-ROD Changes-The selected remedial action alternative was implemented in 1989. The building was decontaminated but could not be released for unrestricted use because of the potential for additional radiological contamination in inaccessible locations such as behind structural members and in sheet metal 
laps. Because the cost of achieving free release would exceed the value of the building, the selected alternative was changed to demolition.

An Explanation of Significant Differences will be prepared at the conclusion of GJPORAP remedial action activities to address departures from the ROD, including the demolition of Building 34 .

\section{Characterization}

In 1982, Building 34 was surveyed for gamma exposure rates. In 1986, the building was surveyed for alpha contamination, gamma exposure rates, radium-226 ( $\mathrm{Ra}-226)$ concentrations of the underlying soil, and radon decay-product (RDC) concentrations. After decontamination operations in 1989 , the building was surveyed regularly to ensure that site personnel were not exposed to radiological risks. The building was included in the 1993 comprehensive survey of facility radiological conditions. These surveys included measurements of gamma exposure rates and alpha and beta-gamma scans, direct measurements, and smears. Additional gamma and beta-gamma survey data, soil samples, and a sample of expansion joint material were collected in 1995.

Radiological Contamination-In the 1986 survey, no alpha activity, gamma exposure rates, or Ra-226 concentrations exceeding the guidelines were detected, but $R D C s$ ranging as high as 1.48 working levels (WL) were recorded (DOE 1986). In 1993, fixed beta-gamma surface activities ranging as high as 32,571 disintegrations per minute per 100 square centimeters $\left(\mathrm{dpm} / 100 \mathrm{~cm}^{2}\right)$ were identified on the concrete foundation and the steel surfaces of Building 34 (Chem-Nuclear Geotech, Inc. 1993). Analysis of a sample of expansion joint material collected from the perimeter of the building indicated Ra-226, thorium-230 (Th-230), and total uranium concentrations of $9.5,62.4$, and 78.3 picocuries per gram $(\mathrm{pCi} / \mathrm{g}$ ), respectively (DOE 1995b).

Nonradiological Contamination-Asbestos insulation on steam pipes and asbestos cement board were removed in 1987. Nonfriable asbestos was identified in window caulking.

\section{Remedial Design}

Specifications for the 1989 decontamination work were included in the design for Construction Phase IA. In 1995, a preliminary design investigation was conducted to assess the physical condition and extent of contamination in Building 34 (Rust 1995). The remedial design for the demolition of Building 34 called for dismantling the structure and, as a separate contract activity, removing the concrete

Table 1 Applicable or Relevant and Appropriate Standards

\begin{tabular}{|l|l|}
\hline \multicolumn{1}{|c|}{ Type of Occurrence } & \multicolumn{1}{c|}{ Standard } \\
\hline Contamination in Soil & $\begin{array}{l}40 \text { CFR 192 } \\
\text { FUSRAP/SFMP Guidelines } \\
\text { DOE Order 5400.5 }\end{array}$ \\
\hline Surface Activity (structural surfaces) & $\begin{array}{l}\text { FUSRAP/SFMP Guidelines } \\
\text { DOE Order 5400.5 }\end{array}$ \\
\hline Gamma Exposure Rate (interior areas) & $\begin{array}{l}40 \text { CFR 192 } \\
\text { FUSRAP/SFMP Guidelines } \\
\text { DOE Order 5400.5 }\end{array}$ \\
\hline Radon Decay-Product Concentration (interior areas) & $\begin{array}{l}40 \text { CFR 192a } \\
\text { FUSRAP/SFMP Guidelines } \\
\text { DOE Order 5400.5 }\end{array}$ \\
\hline
\end{tabular}

aTitle 40, U.S. Code of Federal Regulations (CFR) Section 192, "Health and Environmental Protection Standards for Uranium and Thorium Mill Tailings."

'Guidelines for Residual Radioactive Material at Formerly Utilized Sites Remedial Action Program [FUSRAP] and Remote Surplus Facilities Management Program Sites, (DOE 1987b).

'DOE Order 5400.5, Radiation Protection of the Public and the Environment. 
foundation and floor slab. All materials were surveyed and uncontaminated materials were unconditionally released for salvage or disposal at the Mesa County Landfill. Radiologically contaminated materials were disposed at the Cheney Disposal Cell. After the removal of uranium mill tailings and other associated contaminated material, the remediated area was reconstructed.

\section{Decontamination Operations}

Summary of Remedial Action-Building 34 was decontaminated to a condition of controlled access in January 1989 during Construction Phase IA. The process included chipping fixed beta-gamma contamination from portions of the concrete foundation and approximately $15 \mathrm{ft}^{2}$ $\left(1.4 \mathrm{~m}^{2}\right)$ of the concrete floor; brushing, vacuuming, and sweeping contaminated dust from horizontal surfaces; and removing a contaminated vent. The exterior areas adjacent to Building 34 were remediated in 1989 during Construction Phase IB (Figure 2).

The above-ground structure of Building 34 was removed in January 1996 and the concrete slab and foundation and some of the underlying soil were removed in April 1996. The remediation process involved disassembling the steel building and breaking up the foundation and floor slab. Contaminated materials were hauled by truck to the Cheney Disposal Cell. Uncontaminated materials were surveyed and unconditionally released in accordance with the Rust Health and Safety Desktop Procedures Manual and either salvaged or disposed at the Mesa County Landfill. The windows with the asbestos-containing putty were found to be free of radiological contamination and were disposed at the Mesa County Landfill.

Radiological Contamination-The steel structural members were found to have fixed beta-gamma surface contamination in previously inaccessible areas ranging as high as $20,000 \mathrm{dpm} / 100 \mathrm{~cm}^{2}$; these were decontaminated and unconditionally released (Rust 1996a). Radiologically contaminated building debris, including sheet metal siding and concrete, was removed from within the area of Building 34 , as indicated by the results of soil sample analyses and gamma exposure rate scans.

Radiological Contamination with Associated Nonradiological Contaminants-A sample of roof flashing was found to contain 880,000 micrograms per liter $(\mu \mathrm{g} / \mathrm{L})$ of leachable lead when analyzed using the Toxicity Characteristic Leach Procedure method, which exceeds the RCRA regulatory limit of $500 \mu \mathrm{g} / \mathrm{L}$ for this metal (DOE 1996). Asbestos-containing mastic was identified adhering to the flashing. This waste is currently controlled and managed at the DOE-GJPO facility in accordance with the RCRA Treatment, Storage, and Disposal permit for DOE-GJPO pending treatment and/or disposal at an approved facility. Asbestoscontaining mastic was identified on other building components, which were disposed at the Cheney Disposal Cell.

\section{Final Release Survey}

The final status survey of the soil underlying the location of Building 34 was conducted in accordance with the Survey Plan for Releasing the Buildings at the Grand Junction Projects Office for Unrestricted Use (DOE 1995a), as modified in March 1996 (Rust 1996b). The area of Building 34 was classified as affected because of the potential for contamination exceeding the cleanup criteria. One survey unit was established on the soil surface remaining after removal of the concrete foundation.

Oak Ridge National Laboratory at Grand Junction was the independent verification contractor (IVC) for GJPORAP. Oversight activities were conducted by RAC QA personnel and by representatives of the Colorado Department of Public Health and Environment.

\section{Instrumentation}

Radiation detection instruments were calibrated and used in accordance with the Rust Field Assessments Procedures Manual. The instruments were checked for current calibration and proper operation before and after each 


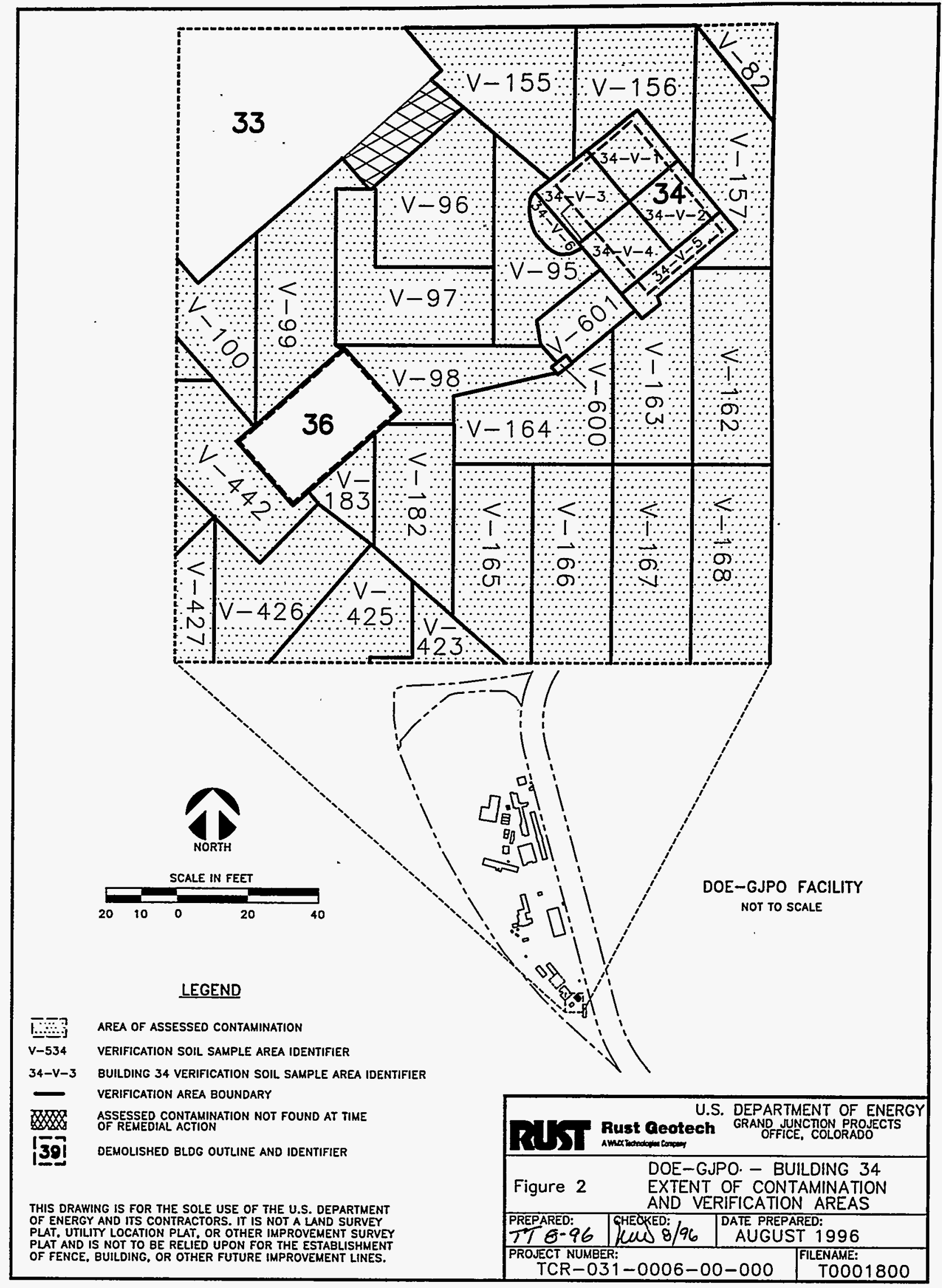

Figure 2. Extent of Contamination and Verification Areas 
survey. Calibrations used traceable standards and complied with 10 CFR 835, "Occupational Radiation Protection" and DOE Order 5480.4, Environmental Protection, Safety, and Health Protection Standards.

\section{Background Determinations}

Background values determined for the DOE-GJPO facility are summarized in Table 2.

\section{Reference Grids}

- Six verification areas ( $\mathrm{V}$-areas) less than or equal to $25 \mathrm{~m}^{2}$ each were established over the area of Building 34 and referenced to the documented location of the building.

\section{Scanning Results}

No structural surfaces remain in this area; therefore, direct scanning for alpha or betagamma surface activity was not conducted. One hundred percent of the exposed soil surface was scanned for gamma activity; gamma exposure rates ranged from 14 to 17 microroentgens per hour $(\mu R / h)$, as presented in Appendix B, Table B-1.

\section{Direct Measurements}

No structural surfaces remain in this area; therefore, direct measurements for alpha or betagamma surface activity were not taken.

\section{Sample Results}

Soil samples comprising up to 4 aliquots, representing the first 6 inches ( 15 centimeters) of soil in the bottom of the excavation, were collected systematically from each V-area. Because the radionuclide concentrations of all $\mathrm{V}$-areas, each $25 \mathrm{~m}^{2}$ or less, were below the authorized limits, the mean radionuclide concentrations of any $100 \mathrm{~m}^{2}$ area on the remediated surface will be below the authorized limits (Appendix B, Table B-1). The soil sample and gamma scan results demonstrate that the radionuclide concentrations in the remediated area do not exceed the hot spot criterion. The upper limit of the mean radionuclide concentrations were calculated at the 95 percent confidence level; the soil within the remediated area complies with the cleanup standards

(Appendix B, Table B-1).

\section{Gamma Exposure Rates}

No interior areas remain after demolition of Building 34; therefore, gamma exposure rate measurements were not taken.

\section{Cost and Schedule}

Project costs and the schedule for the remediation of Building 34 will be presented in the summary final report of the GJPORAP remediation of interior areas.

\section{Occupational Exposure}

The results of personnel and area monitoring of exposure of workers and the public to radiological and nonradiological hazards resulting from GJPORAP-related activities indicated no above-background exposures to

Table 2. Background Values for the DOE-GJPO Facility

\begin{tabular}{|l|c|l|}
\hline \multicolumn{1}{|c|}{ Criterion } & Background Value & Source of Data \\
\hline Gamma Exposure Rate-Exterior & $14 \mu \mathrm{R} / \mathrm{h}$ & DOE 1986 \\
\hline Radium-226 Concentration in Soil & $1.0 \mathrm{pCi} / \mathrm{g}$ & DOE 1990b \\
\hline Thorium-230 Concentration in Soil & $2.0 \mathrm{pCi} / \mathrm{g}$ & DOE 1990b \\
\hline Total Uranium Concentration in Soil & $2.0 \mathrm{pCi} / \mathrm{g}$ & DOE 1990b \\
\hline
\end{tabular}

Key: $\mu \mathrm{R} / \mathrm{h}=$ microroentgens per hour; $\mathrm{pCi} / \mathrm{g}=$ picocuries per gram 
radioparticulates, including radon daughters, ionizing radiation, or other hazards.

\section{Waste Volumes}

The remediation of Building 34 generated a total of 100 tons (91 metric tons) of contaminated material, representing a volume of approximately $78 \mathrm{yd}^{3}\left(60 \mathrm{~m}^{3}\right)$ (Rust 1996c). This material was disposed at the Cheney Disposal Cell.

\section{Final Condition}

All release requirements identified for GJPORAP have been met for the soil at the former location of Building 34 (Table 3 ). The IVC will issue a Statement of Verification to signify its concurrence that this portion of the remedial action has achieved program objectives.

Radiologically contaminated material has been removed, and all remediated areas comply with the applicable provisions of 40 CFR 192, FUSRAP/SFMP guidelines, and DOE Order 5400.5. Suspected occurrences of nonradiological contamination have been investigated, and all identified occurrences of nonradiological contamination have been remediated.

Remediated areas have been restored to comply with floodplain permits, the Endangered Species Act, and other applicable regulations. Groundwater sampling will provide further assurance that contaminated materials currently managed on site will not pose any threat to human health or the environment. Sufficient data have been collected to document the final site conditions and to demonstrate that the cleanup levels specified in the ROD were attained. These data and associated information are available to the public and will be archived in the Certification Docket.

Because of the limitations of current technology and procedures for identifying and remediating radiologically contaminated materials, unknown deposits of contamination may be found in the future. The potential for encountering contamination during future construction activities will be determined and atrisk activities will be monitored for radiologicaland nonradiological contamination. The DOE-GJPO facility is routinely surveyed for radiation and other hazards.

No assessed hazardous substances were left in the remediated area; it can be released for unrestricted use and unlimited exposure. At the time of this report, contamination is still present in other interior areas of the DOE-GJPO facility; access to these areas is controlled and will be addressed by future GJPORAP remedial actions. After the interior remedial action is completed, the facility will be managed as an LTSM site by DOE until restoration of the alluvial aquifer by natural flushing has occurred.

\section{Lessons Learned}

Lessons learned during remediation of Building 34 have been incorporated into subsequent operations. These lessons will be presented in a summary final report of the GJPORAP remediation of the interior areas. 
Table 3. Building 34 Certification Summary

\begin{tabular}{|c|c|c|c|}
\hline \multicolumn{4}{|c|}{ Survey Unit: Excavation Surface (affected area, exterior soil surface) } \\
\hline $\begin{array}{l}\text { Certification } \\
\text { Criteria }\end{array}$ & $\begin{array}{l}\text { Authorized } \\
\text { Limit }\end{array}$ & $\begin{array}{l}\text { Number of } \\
\text { Observations }\end{array}$ & Results \\
\hline $\begin{array}{l}\text { Gamma Exposure } \\
\text { Rate (habitable } \\
\text { areas only) }\end{array}$ & $<20 \mu \mathrm{R} / \mathrm{h}$ above backgroung ${ }^{\mathrm{a}}$ & None & $\begin{array}{l}\text { Not applicable (no habitable } \\
\text { areas). }\end{array}$ \\
\hline $\begin{array}{l}\text { Radon Decay- } \\
\text { Product } \\
\text { Concentration } \\
\text { (habitable areas } \\
\text { only) }\end{array}$ & $\begin{array}{l}\text { Annual average shall not exceed } \\
0.02 \text { WL, to the extent practicable, } \\
\text { and in no case shall exceed } \\
0.03 \text { WL. }\end{array}$ & None & $\begin{array}{l}\text { Not applicable (no habitable } \\
\text { areas). }\end{array}$ \\
\hline Scans & $\begin{array}{l}\text { Elevated activity will be } \\
\text { investigated. }\end{array}$ & $\begin{array}{l}\text { Gamma: } \\
\text { scanned } \\
100 \text { percent of } \\
\text { surface } \\
\text { Alpha and beta- } \\
\text { gamma: none }\end{array}$ & $\begin{array}{l}\text { Gamma: activities did not } \\
\text { exceed backgroung by more } \\
\text { than } 30 \text { percent. } \\
\text { Alpha and beta-gamma: not } \\
\text { applicable (no structural } \\
\text { surfaces). }\end{array}$ \\
\hline $\begin{array}{l}\text { Surface Activity } \\
\text { (structural surfaces } \\
\text { only) }\end{array}$ & $\begin{array}{l}\text { Alpha or beta-gamma activity shall } \\
\text { not exceed } 5,000 \mathrm{dpm} / 100 \mathrm{~cm}^{2} \\
\text { fixed, } 1,000 \mathrm{dpm} / 100 \mathrm{~cm}^{2} \\
\text { removable, averaged over } 1 \mathrm{~m}^{2} \text {. }\end{array}$ & None & $\begin{array}{l}\text { Not applicable (no structural } \\
\text { surfaces). }\end{array}$ \\
\hline \multirow[t]{2}{*}{$\begin{array}{l}\text { Radionuclide } \\
\text { Concentrations } \\
\text { (soil surfaces only) }\end{array}$} & $\begin{array}{l}\text { Ra-226, and Th-230: } \\
\text { Shall not exceed } 5 \mathrm{pCi} / \mathrm{g} \text { above } \\
\text { background in the } 15-\mathrm{cm} \text { surface } \\
\text { layer, averaged over } 100 \mathrm{~m}^{2} \text {. } \\
\text { Shall not exceed } 15 \mathrm{pCi} / \mathrm{g} \text { above } \\
\text { background in any } 15-\mathrm{cm} \text {-thick soil } \\
\text { layer more than } 15 \mathrm{~cm} \text { below the } \\
\text { surface, averaged over } 100 \mathrm{~m}^{2} \text {. }\end{array}$ & $\begin{array}{l}\text { None } \\
6 \text { composite } \\
\text { samples, each } \\
\text { comprising up } \\
\text { to } 4 \text { aliquots }\end{array}$ & $\begin{array}{l}\text { Not applicable (excavation } \\
>15 \mathrm{~cm} \text { deep). } \\
\text { Ra-226: } 1.3 \mathrm{pCi} / \mathrm{g} \mathrm{maximum}^{\mathrm{b}, \mathrm{c}, \mathrm{d}} \\
\mu_{\alpha}=1.6 \mathrm{pCi} / \mathrm{g}^{\mathrm{b}, \mathrm{c}} \\
\text { Th-230: } 1.2 \mathrm{pCi} / \mathrm{g} \text { maximum } \\
\mu_{\alpha}, \mathrm{c}, \mathrm{d} \\
\mu_{\alpha}=1.2 \mathrm{pCi} / \mathrm{g}^{\mathrm{b}, c}\end{array}$ \\
\hline & $\begin{array}{l}\text { Total uranium: } \\
\text { Shall not exceed } 106 \mathrm{pCi} / \mathrm{g} \text { above } \\
\text { background in any } 15-\mathrm{cm} \text {-thick } \\
\text { layer, averaged over } 100 \mathrm{~m}^{2} \text {. }\end{array}$ & $\begin{array}{l}6 \text { composite } \\
\text { samples, each } \\
\text { comprising up } \\
\text { to } 4 \text { aliquots }\end{array}$ & $\begin{array}{l}3.1 \mathrm{pCi} / \mathrm{g} \operatorname{maximum}^{\mathrm{b}, c, d} \\
\mu_{\alpha}=3.3 \mathrm{pCi} / \mathrm{g}^{\mathrm{b}, c}\end{array}$ \\
\hline Hot Spot Criteria & Limit $={\text { (guideline value })(100 / \text { area })^{0.5}}$ & As required & $\begin{array}{l}\text { Maximum concentrations below } \\
\text { hot spot limit. }\end{array}$ \\
\hline
\end{tabular}

${ }^{8}$ Background activities are summarized in Table 2.

bamma exposure rate and radionuclide concentrations include background.

${ }^{c}$ Radionuclide concentrations were determined by laboratory analysis.

These maxima were determined for the $100 \mathrm{~m}^{2}$ areas designated in Appendix B, Table B-2.

Note: Th-232 is not a contaminant of concern at the DOE-GJPO facility (DOE 1994).

Key:

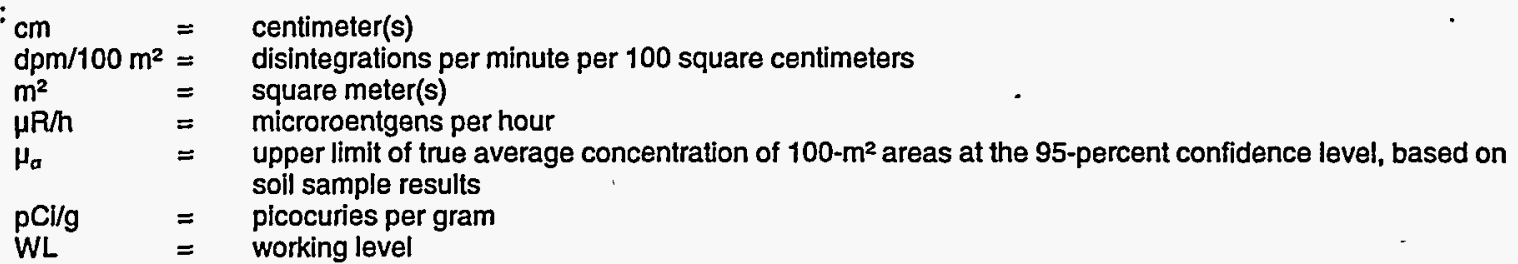




\section{References}

10 CFR 830. U.S. Department of Energy, "Nuclear Safety Management," U.S. Code of Federal Regulations.

40 CFR 192. U.S. Environmental Protection Agency, "Health and Environmental Protection Standards for Uranium and Thorium Mill Tailings," U.S. Code of Federal Regulations.

American Society of Mechanical Engineers (ASME), 1989. Quality Assurance Program for Nuclear Facilities, NQA-1, New York.

Chem-Nuclear Geotech, Inc., 1993.

"Comprehensive Building Survey Results for Building 34 (Revision 1)" memorandum from K.D. Briar to D.M. Frye, U.S. Department of Energy Grand Junction Projects Office, Grand Junction, Colorado, October 14.

Rust Geotech. Field Assessments Procedures Manual, U.S. Department of Energy Grand Junction Projects Office, Grand Junction, Colorado.

Health and Safety Desktop

Procedures Manual (Manual 303), U.S. Department of Energy Grand Junction Projects Office, Grand Junction, Colorado.

Quality Assurance Manual (Manual 101), U.S. Department of Energy Grand Junction Projects Office, Grand Junction, Colorado.

1995. "Preliminary Investigation Report for Building 34," memorandum from J.E. Bennett to D.A. Gehring, U.S. Department of Energy Grand Junction Projects Office, Grand Junction, Colorado, November 14.

1996a. "Contaminated Material from Building 34," memorandum from R. Simmons to D.A. Gehring, U.S. Department of Energy Grand Junction Projects Office, Grand Junction, Colorado, February 23.

1996b. "Change to the Survey Plan for Releasing the Buildings at the Grand
Junction Projects Office for Unrestricted Use," memorandum from K.A. Cary to the GJPORAP Project Record, U.S. Department of Energy Grand Junction Projects Office, Grand Junction, Colorado, March 13.

1996c. "Estimated Quantities of GJPORAP Contaminated Construction Materials," memorandum from D.A. Gehring to the project record, U.S. Department of Energy Grand Junction Projects Office, Grand Junction, Colorado, May 13.

U.S. Department of Energy (DOE), 1986. Radiologic Characterization of the Department of Energy Grand Junction Projects Office Facility, GJ-41, prepared by Bendix Field Engineering Corporation for the U.S. Department of Energy Grand Junction Projects Office, Grand Junction, Colorado, January. 1987a. Historical Survey of the Grand Junction Projects Office FacilityHazardous (Non-radioactive) Wastes, prepared by UNC Technical Services, Inc., for the U.S. Department of Energy Grand Junction Projects Office, Grand Junction, Colorado, February. 1987b. Guidelines for Residual Radioactive Material at Formerly Utilized Sites Remedial Action Program and Remote Surplus Facilities Management Program Sites, Rev. 2, March. 1989a. Final Remedial Investigation/Feasibility Study—Environmental Assessment for the U.S. Department of Energy Grand Junction (Colorado) Projects Office Facility, DOE/EA-0402, prepared by UNC Geotech, Inc., for the U.S. Department of Energy Grand Junction Projects Office, Grand Junction, Colorado, July.

, 1989b. "Review of Remedial Investigation/Feasibility Study (RI/FS) for a Site Which Is Not Included on the National Priorities List (NPL)," letter from Dee Williamson, U.S. Department of Energy Grand Junction Projects Office, to David Schaller, U.S. Environmental Protection Agency Region VIII, Grand Junction, Colorado, August 4. 
1990a. Grand Junction Projects

Office Remedial Action Project, Declaration for the Record of Decision and Record of Decision Summary [includes the Responsiveness Summary], prepared by UNC Geotech, Inc., for the U.S. Department of Energy Grand Junction Projects Office, Grand Junction, Colorado, April. 1990b. Grand Junction Projects Office Remedial Action Project, Radiological Assessment for Construction Phase IB, prepared by UNC Geotech, Inc., for the U.S. Department of Energy Grand Junction Projects Office, Grand Junction, Colorado, April.

, 1990c. Grand Junction Projects Office Remedial Action Project Remedial Action Plan, P-GJPO-142, prepared by UNC Geotech, Inc., for the U.S. Department of Energy Grand Junction Projects Office, Grand Junction, Colorado, December.

, 1994. Grand Junction Projects Office Remedial Action Project, Justification for Certifying 47 Large-Area Verification Areas at the Grand Junction Projects Office,

GJ-GJPO-94-1, prepared by Rust for the U.S. Department of Energy Grand Junction Projects Office, Grand Junction, Colorado, November.

1995a. Release Survey Plan for the

Buildings at the Grand Junction Projects Office, prepared by Rust for the U.S. Department of Energy Grand Junction Projects Office, Grand Junction, Colorado, 1995. 1995b. Analytical Report,

Requisition No. 14467, prepared by Rust for the U.S. Department of Energy Grand Junction Projects Office, Grand Junction, Colorado, December 22.

1996. Analytical Report,

Requisition No. 14734, prepared by Rust for the U.S. Department of Energy Grand Junction Projects Office, Grand Junction, Colorado, May 14.

DOE Order 5400.5, Radiation Protection of the Public and the Environment, Change 1.

DOE Order 5480.1B, Environment, Safety, and Health Program for Department of Energy Operations, Change 5.

DOE Order 5480.4, Environmental Protection, Safety, and Health Protection Standards.

DOE Order 5480.11, Radiation Protection for Occupational Workers, Change 2. 
This page intentionally blank

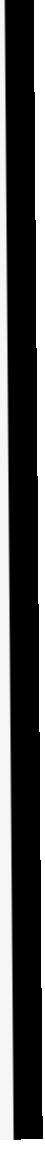




\section{Appendix A}

Applicable Program and Quality Assurance Requirements and Procedures 
This page intentionally blank 


\section{GJPORAP Program Management}

Operations Management Policy Manual

(Manual 104)

Project Control System Manual (Manual 107)

Management Policies Manual (Manual 100), Section 1, "General Administration," and Section 12, "Organization Functions and Responsibilities"

Remedial Action Statements of Work

Grand Junction Projects Office Desk Procedures Manual

Grand Junction Projects Office Remedial Action Project (GJPORAP), Grand Junction, Colorado, Community Relations Plan Update

Grand Junction Projects Office Remedial Action Project Quality Assurance Program Plan, P-GJPO-141

Grand Junction Projects Office Remedial Action Project Records Management Plan, P-GJPO-143

\section{GJPORAP Construction Management}

Operations Management Policy Manual

(Manual 104)

Operations Department Construction

Procedures Manual

\section{Engineering}

Engineering Process Planning Guidelines

AutoCAD Standards Manual

\section{Assessment/Verification}

Land Survey Support Procedures

AutoCAD Standards Manual
Environmental Procedures Catalog

(Manual 116)

\section{Laboratory Services}

\section{Analytical Laboratory}

Analytical Chemistry Laboratory Administrative Plan and Quality Control Procedures

Analytical Chemistry Laboratory Handbook of Analytical and Sample Preparation Procedures, Volumes I, II, and III

Gamma-Ray Spectroscopy System Operations Methods Manual

\section{Environmental Instrumentation Laboratory}

Calibration Control Program for Measurement and Test Equipment and Measurement Standards

Electronics Laboratory Procedures

\section{Quality Assurance}

Quality Assurance Desk Instructions and Administrative Procedures Manual

(Manual 301)

\section{Health, Safety, and Security}

Grand Junction Projects Office Remedial Action Project Health and Safety Plan, P-GJPO-144

Health and Safety Manual (Manual 103)

Volumes 1 and 2

\section{Contracts and Procurement}

Management Policies Manual (Manual 100), Section 5, "Procurement"

Procurement Manual

Stores, Property, and Transportation (SPAT)

Manual (Manual 114)

Rust Guide for Preparing a Purchase

Requisition 


\section{Information Services}

\section{Computer Support}

Information Services Manual (Manual 105)

Publications and Records

Management Policies Manual (Manual 100), Section 2, "Documentation Systems," and Section 13, "Records Management"

\section{Human Resources}

Training and Employee Development

Management Policies Manual (Manual 100), Section 3, "Human Resources"

\section{Other Guidance}

40 CFR 261, "Identification and Listing of Hazardous Waste."

40 CFR 300, "National Oil and Hazardous Substances Pollution Contingency Plan."

A Manual for Implementing Residual Radioactive Material Guidelines Using RESRAD Version 4.0, Argonne National Laboratory, June 1989.

"Approval of the Grand Junction Projects Office Remedial Action Project: National Environmental Policy Act and Comprehensive Environmental Response Compensation, and Liability Act Documents" [includes the FONSI for GJPORAP], DOE, February 29, 1990.

"Calculation of Total Uranium Specific Activity From Total Uranium Chemical Concentration by Weight," Rust Geotech, November 11, 1994.

Community Relations in Superfund: A Handbook, EPA, January 1992.

Defense Decontamination and Decommissioning Program: Program Management Plan, DOE, December 1989.

DOE Order 4700.5, Project Control System Guidelines.
DOE Order 5400.4, Comprehensive

Environmental Response, Compensation, and Liability Act Requirements.

DOE Order 5700.6C, Quality Assurance.

DOE Order 5820.2A, Radioactive Waste Management.

Exemption No. DOT-E 10594, Research and Special Programs Administration, U.S. Department of Transportation, May 28, 1992.

Environmental Implementation Guide for Radiological Survey Procedures, draft report, DOE, November 1992.

Grand Junction Projects Office Remedial Action Project, Radiological Sampling and Verification Plan, Phase IVA, DOE, November 1993.

Guidelines for Decontamination of Facilities and Equipment Prior to Release for Unrestricted Use or Termination of Licenses for Byproduct, Source, or Special Nuclear Material, U.S. Nuclear Regulatory Commission, 1982.

Interim Final Guidance on Preparing Superfund Decision Documents: The Proposed Plan, The Record of Decision, Explanation of Significant Differences, The Record of Decision Amendment, EPA, July 1989.

Limits for Intakes of Radionuclides by Workers, International Commission on Radiological Protection (ICRP), August 1982.

Manual for Conducting Radiological Surveys in Support of License Termination, NUREG/CR 5849, Oak Ridge Associated Universities, June 1992.

Procedures for Completion and Deletion of National Priority List Sites, U.S. Environmental Protection Agency (EPA), October 1988.

Project Plan for the U.S. Department of Energy Grand Junction Projects Office Remedial Action Project, DOE, March 1986. 
"Proposed GJPORAP Release Criteria and Scope Impacts," DOE, July 20, 1989.

Public Participation in Environmental Restoration Activities, DOE, November 1991.

Radiometric Survey of the Grand Junction Facility, (DOE), May 1982.

Recommendations of the ICRP, ICRP, August 1987.

Record of Decision for Remedial Action at the Climax Uranium Company Uranium Mill Site, Grand Junction, Colorado, DOE, August 1988.
SFMP Resource Manual, DOE, 1989.

Verification and Certification Protocol for the Office of Environmental Restoration, Formerly Utilized Sites Remedial Action Program and Decontamination and Decommissioning Program, Rev. 3, DOE, November 1990.

Work Plan for Independent Verification of the Grand Junction Projects Office Remedial Action Project, Oak Ridge National Laboratory, October 1991. 
This page intentionally blank

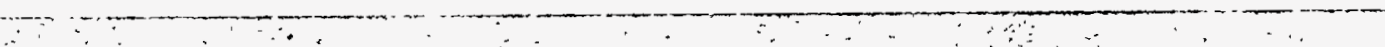




\section{Appendix B}

\section{Final Radiological Conditions}


This page intentionally blank

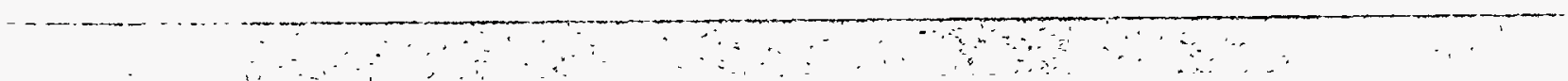


Table B-1 summarizes the post-remediation sampling and measurement results for the soils underlying the site of Building 34. The samples were acquired prior to backfilling. Each sample is a composite of individual aliquots representing the 6-inch-thick soil layer at the bottom of the excavation. The samples were analyzed for radium-226 (Ra-226) using the Opposed Crystal System (OCS) and for Ra-226, thorium-230 (Th-230), and total uranium by the U.S. Department of Energy Grand Junction Projects Office analytical laboratory. The concentrations of these radionuclides are expressed in picocuries per gram ( $\mathrm{pCi} / \mathrm{g}$ ) and include background. The post-remediation gamma exposure rate ranges are expressed in microroentgens per hour $(\mu \mathrm{R} / \mathrm{h})$. Contiguous verification areas (V-areas) were grouped into $100-\mathrm{m}^{2}$ areas to demonstrate compliance with the release criteria for soils (Table B-2). The remediated area is shown on Figure 2.

Table B-1. Post-Remediation Sample/Measurement Results for Exterior Soil Areas

\begin{tabular}{|c|c|c|c|c|c|c|c|}
\hline \multirow[b]{2}{*}{$\begin{array}{l}\text { Verification } \\
\text { Area }\end{array}$} & \multirow[b]{2}{*}{$\begin{array}{c}\text { Gamma } \\
\text { Exposure } \\
\text { Rate }(\mu R / h)\end{array}$} & \multirow[b]{2}{*}{$\begin{array}{l}\text { Soil Sample } \\
\text { Ticket No. }\end{array}$} & \multicolumn{4}{|c|}{ Concentration (pCi/g) } & \multirow[b]{2}{*}{$\begin{array}{l}\text { Average Depth } \\
\text { of Excavation } \\
\text { (inches) }\end{array}$} \\
\hline & & & $\begin{array}{l}\text { Ra-226 } \\
\text { (OCS) }\end{array}$ & $\begin{array}{c}\text { Ra-226 } \\
\text { (lab) }\end{array}$ & $\begin{array}{c}\text { Th-230 } \\
\text { (lab) }\end{array}$ & $\begin{array}{l}\text { Total } \\
\text { Uranium } \\
\text { (lab) }\end{array}$ & \\
\hline $34-V-1$ & $14-16$ & NCK 778 & 1.8 & 1.3 & 1.1 & 3.6 & 24 \\
\hline $34-V-2$ & $14-16$ & NCK 779 & 1.5 & 1.6 & 1.2 & 3.5 & 24 \\
\hline $34-V-3$ & $14-17$ & NCK 780 & 2.9 & 0.3 & 1.3 & 2.8 & 24 \\
\hline $34-V-4$ & $14-17$ & NCK 781 & 3.2 & 1.3 & 1.1 & 2.3 & 18 \\
\hline $34-V-5$ & $14-17$ & NCK 782 & 3.4 & 1.4 & 1.1 & 2.4 & 18 \\
\hline $34-V-6$ & $14-16$ & NCK 783 & 3.1 & 1.3 & 1.1 & 2.0 & 6 \\
\hline Mean & & & 2.7 & 1.2 & 1.2 & 2.8 & \\
\hline s & & & 0.8 & 0.4 & 0.1 & 0.7 & \\
\hline$\mu_{a}^{a}$ & & & 3.3 & 1.6 & 1.2 & 3.3 & \\
\hline
\end{tabular}

${ }^{a}$ Calculated using $n=6$ samples, $d f=5, t-95 \%=2.015$.

Key:

Mean $=$ Arithmetic average of sample values $(\mathrm{pCi} / \mathrm{g})$

$\mu_{\sigma} \quad=$ Upper limit of population mean ( $\mathrm{pCi} / \mathrm{g}$ ) at 95-percent confidence (from equation 8-13 of Manual for Conducting

Radiological Surveys in Support of License Termination [U.S. Nuclear Regulatory Commission 1992])

df $\quad=$ Degrees of freedom $(n-1)$

$n \quad=$ Number of samples

s $\quad=$ Sample standard deviation $(\mathrm{pCi} / \mathrm{g})$

$\mathrm{t}-95 \%=$ Students $\mathrm{t}$ distribution statistic for $\mathrm{n}$ degrees of freedom at 95-percent confidence 
Table B-2. Mean Concentrations of $100-\mathrm{m}^{2}$ Soil Areas

\begin{tabular}{|c|c|c|c|c|c|c|c|c|c|}
\hline \multicolumn{2}{|l|}{$100-m^{2}$ Area $^{a}$} & \multicolumn{8}{|c|}{ Concentration (pCi/g) } \\
\hline \multirow[b]{2}{*}{ V-Areas ${ }^{b}$} & \multirow[b]{2}{*}{$\mathbf{n}$} & \multicolumn{2}{|c|}{ Ra-226 (OCS) } & \multicolumn{2}{|c|}{ Ra-226 (lab) } & \multicolumn{2}{|c|}{ Th-230 (lab) } & \multicolumn{2}{|c|}{ Uranium (lab) } \\
\hline & & Mean & $\mathbf{s}$ & Mean & s & Mean & s & Mean & $\mathbf{s}$ \\
\hline$V-1, V-2, V-3, V-4$ & 4 & 2.4 & 1.3 & 1.1 & 0.6 & 1.2 & 0.1 & 3.1 & 0.6 \\
\hline$v-5, v-6$ & 2 & 3.3 & 0.2 & 1.3 & 0.1 & 1.1 & 0.0 & 2.2 & 0.3 \\
\hline
\end{tabular}

${ }^{a}$ Contiguous V-areas were grouped into $100 \mathrm{~m}^{2}$ areas. Because all soil sample analyses results are below the authorized limits, the average radionuclide concentrations of any $100 \mathrm{~m}^{2}$ areas on the remediated surface will be below the authorized limits.

"All V-Area identifiers are preceded by " 34-."

Key:

Mean $=$ Arithmetic average of sample values $(\mathrm{pCi} / \mathrm{g})$

$\mathrm{n} \quad=$ Number of samples

$\mathrm{s} \quad=$ Sample standard deviation (pCi/g) 